\title{
Discussion of Type Selection and Design on Waterproof Curtainfor Deep-Foundation Pit in Neighbouring Huangpu River Area
}

\author{
Yang Jibao, Dong Linbing \\ Shanghai Municipal Engineering Design Institute (Group) Co. Ltd, Shanghai, China \\ Email address: \\ yjbao2005@163.com (Yang Jibao), donglinbing@163.com (Dong Linbing)
}

\section{To cite this article:}

Yang Jibao, dong Linbing. Discussion of Type Selection and Design on Waterproof Curtainfor Deep-Foundation Pit in Neighbouring Huangpu River Area. International Journal of Natural Resource Ecology and Management. Vol. 3, No. 4, 2018, pp. 53-57.

doi: 10.11648/j.ijnrem.20180304.12

Received: August 13, 2018; Accepted: September 6, 2018; Published: October 13, 2018

\begin{abstract}
Based on the distribution characteristics of burial depth and thickness of confined aquifers adjacent to the Huangpu River area, for the deep-foundation pits of two floors basement, the conventional tri-axial deep stirring pile is usually used to cut off the confined aquifer; for the deep-foundation pits of three floors basement or beyond, the burial depth and thickness of confined aquifer in each site are quite different, correspondingly, the selection and design of the waterproof curtain of the confined aquifer is relatively complicated. In order to induce engineering accidents due to the failure of the water curtain, the problem of confined water had to be studied and dealt seriously and scientifically. Based on the two engineering examples adjacent to the Huangpu River, this paper focuses on the complexity of the confined water problem of the deep-foundation pit projects in three floors basement or beyond, and the selection and design of the waterproof curtain.Different design schemes are recommended by discussing the economy and rationality of design schemes, evaluating construction feasibility and analyzing the complexity of construction quality control. The result of research shows that for the waterproof curtain of the deep-foundation pit in three floors underground or more, considering the large construction depth, the TRD method and the underground diaphragm wall are better.
\end{abstract}

Keywords: Deep-Foundation Pit,Waterproof Curtain,More Than Three Floors Underground,

Adjacent to Huangpu River Area

\section{Introduction}

With the construction of urban infrastructure facilities and the development and utilization of underground space, the underground complex projects in coastal cities such as Shanghai increase, and deep-foundation pit engineering extensively appears in varioustypes of construction engineering.

In the deep-foundation pit engineering, if the pit can't keep the balance between the overlaying soil of the confined aquifer roof at the bottom and the roof force of the confined water, water-inrush will happen to the bottom of the pit. Since the water-inrush occurs instantaneously, it is difficult to take effective measures in time, which may easily cause pit engineering accidents and endanger the safety of the surrounding environment [1].
In order to prevent the occurrence of water-inrush, it is usually necessary to reduce the confined water head during the excavation of the foundation pit to reduce the topping force of the confined head. The reduction of the confined water head will cause the consolidation and settlement of the soil around the foundation pit, thus affecting the safety of the surrounding environment. The waterproof curtain for deep-foundation pit passes through a confined aquifer that affects the foundation pit project, and enters a certain depth of the relatively impervious layer,so as to achieve the hydraulic connection of the confined aquifer between inside and outside of the foundation pit, which reducesthe impact of pumping the confined water on the surrounding environment.

InShanghai, the confined aquifer affecting the foundation pit project is as follows: the $(5)_{2}$ sandy silt stratum (the micro-pressure aquifer), the (7) fine sand layer (the first 
confined aquifer) and the (9) medium-sand seam (the second confined aquifer) [2]. For one floor basement, the excavation of the foundation pit generally does not involve the problem of confined water; for two floors basement, the excavation of the foundation pit may involve the problem of micro-confined water in the $(5)_{2}$ sandy silt stratum, while for three floors basement or beyond, the excavation of the foundation pit may involve the problem of the micro-confined water of the $(5)_{2}$ sandy silt stratum and the confined water of the (7) fine sand layer; since the burial depth of the (9) medium-sand seam is deeper (generally over $60 \mathrm{~m}$ ), the excavation of the foundation pit less than $20 \mathrm{~m}$ is generally not involved.

Based on the distribution characteristics of burial depth and thickness of confined aquifers adjacent to the Huangpu River area, for the deep-foundation pits of two floors basement, the conventional tri-axial deep stirring pile is usually used to cut off the confined aquifer; for the deep-foundation pits of three floors basement or beyond, the burial depth and thickness of the $(5)_{2}$ micro-confined aquifer and the (7) confined aquifer in each site are quite different, correspondingly, the selection and design of the waterproof curtain of the confined aquifer is relatively complicated [3].

Adjacent to the Huangpu River area, the pressure water in the site is close, and there is usually a certain hydraulic connection with the Huangpu River. Once the water-inrush of the bottom of the foundation pit occurs due to the failure of the water curtain, the confined water at the bottom of the pit will continue to flow. The confined water replenished from the Huangpu River, which makes the treatment difficult and even causesfatal engineering accidents. For this reason, the problem of confined water had to be studied and dealt seriously and scientifically.

Based on the two engineering examples adjacent to the Huangpu River, this paper focuses on the complexity of the confined water problem of the deep-foundation pit projects in the three floors basement or beyond, and the selection and design of the waterproof curtain, which offers references for the design of the similar deep-foundation pit projects.

\section{Enterprise Tiandi Project in Foreshore}

The proposed site is located in the west of Jiyang Road in Pudong New Area, north of Yaoti Road, adjacent to the Oriental Sports Center, and about $500 \mathrm{~m}$ away from Huangpu River. There is a three-story basement in the project.The excavation area of the foundation pit is about $16,000 \mathrm{~m}^{2}$ and the excavation depth offoundation pit is $15.2 \mathrm{~m}$. The east side of the foundation pit is adjacent to the main urban traffic road Jiyang Road elevated, and the elevated pier is about $51.2 \mathrm{~m}$ away from the excavation sideline of the foundation pit. According to Shanghai Municipal Industry Standard "Technical Standards for Urban Bridges and Tunnel Safety Protection Areas" (Shanghai Jianjiao [2010] No. 511), for the bridge, the safety protection area of the first-level foundation pit bridge is $65 \mathrm{~m}$. This elevated frame is in the safety protection area and needs to be protected.

\subsection{Geological Conditions}

There is the $(5)_{2-1}$ layer and the $(5)_{2-3}$ layer of micro-confined aquifers under the site, which have the following characteristics: i) Micro-confined water head is higher: According to the results of pumping test, the average depth of the (5) $)_{2-1}$ water level is $4.7 \mathrm{~m}$, and the average buried depth of the $(5)_{2-3}$ water level is $4.9 \mathrm{~m}$; ii) the depth of the micro-confined water is shallower: the buried depth of the $(5)_{2-1}$ roof is about $18.8 \mathrm{~m}$, only $3.6 \mathrm{~m}$ away from the bottom of the foundation pit; iii) the thickness of the micro-confined aquifer is thicker: the thickness of the $(5)_{2-1}$ layer is about $4.7 \mathrm{~m}$, while the thickness of the $(5)_{2-3}$ layer is about $5.5 \mathrm{~m}$, and the in the middle, the $(5)_{2-2}$ layer is sandwiched with thin layer of powdery soil, which is extremely permeable, actually the most middle part of the $(5)_{2-1}$ layer and the $(5)_{2-3}$ layer is penetrated, so that the $(5)_{2-1}$ layer, the $(5)_{2-2}$ layer, and the $(5)_{2-3}$ layer are integrally formed as a micro-confinedaquifer with a layer thickness of about $13 \mathrm{~m}$. The site geological conditions are shown in Figure 1.

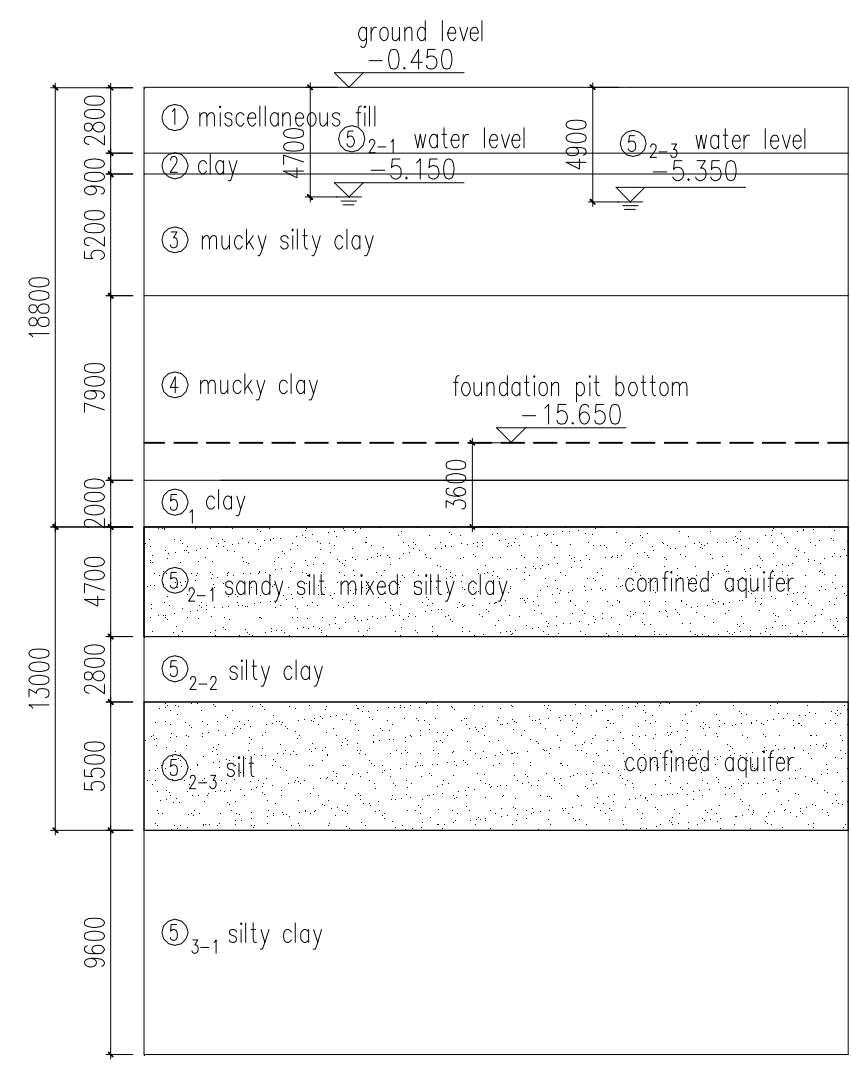

Figure 1. The site geological conditions.

\subsection{Deep-Foundation Pit Support Design}

The retaining structure type of the bored pile and the waterproof curtain is adopted, and the horizontal support system is three-way reinforced concrete support.

After the anti-surge stability check, the (5) $2-1$ and $(5)_{2-3}$ layers of micro-confined aquifers have the possibility of water-inrush, and the water level of the micro-confined aquifer needs to be reduced during the excavation process.

In the east side of the deep-foundation pit, there is an elevated 
which needs to be protected. In order to reduce the impact ofpumping the confined water on the surrounding environment, the survey report recommends that the waterproof curtain be inserted into the (5) $)_{3-1}$ layer silty clay [4].

In order to completely block the micro-confined aquifer, the waterproof curtain needs to be inserted into a certain depth in the $(5)_{3-1}$ layer. According to the depth and thickness of the micro-confined aquifer in the site, the length of the waterproof curtain must reach about $35 \mathrm{~m}$.

\subsection{Comparison of Waterproof Curtain Schemes}

According to the length requirements of the required waterproof curtain, there are several types of waterproof curtains, such as tri-axial deep stirring pile, TRD method (Trench cutting Re-mixing Deep wall method) and underground continuous wall. The cost comparison of the waterproof curtainsis shown in Table 1.

Table 1. The cost comparison of the waterproof curtains.

\begin{tabular}{|c|c|c|c|}
\hline type & Cast-in-place pile row + ultra-deep tri-axial mixing pile & Cast-in-place pile row +TRD method & underground continuous wall \\
\hline \multirow{2}{*}{ specification } & 1000@1200 Cast-in-place pile+ & 1000@1200 Cast-in-place pile & 800 thick \\
\hline & 850@1200 tri-axial mixing pile & +700thick TRD method & underground continuous wall \\
\hline \multirow{2}{*}{ workload } & Cast-in-place pile: $10480 \mathrm{~m}^{3}$ & Cast-in-place pile: $10480 \mathrm{~m}^{3}$, & underground continuous wall: \\
\hline & Tri-axial mixing pile: $15320 \mathrm{~m}^{3}$ & TRD method: $13230 \mathrm{~m}^{3}$ & $14900 \mathrm{~m}^{3}$ \\
\hline \multirow{2}{*}{$\begin{array}{l}\text { price } \\
\text { total project } \\
\text { cost }\end{array}$} & $\begin{array}{l}\text { Cast-in-place pile: RMB } 1500 / \mathrm{m}^{3} \text {, } \\
\text { Tri-axial mixing pile: RMB } 450 / \mathrm{m}^{3}\end{array}$ & $\begin{array}{l}\text { Cast-in-place pile: RMB } 1500 / \mathrm{m}^{3} \text {, } \\
\text { TRD method: RMB } 750 / \mathrm{m}^{3}\end{array}$ & $\begin{array}{l}\text { underground continuous wall: } \\
\text { RMB } 2400 / \mathrm{m}^{3}\end{array}$ \\
\hline & RMB 22.6millions & RMB 25.6millions & RMB 35.8 millions \\
\hline
\end{tabular}

According to the comparative analysis of the cost of the waterproof curtains, the cost of using bored pile and tri-axial deep stirring pile is relatively low. However, due to the limitations of current construction machinery and other conditions, the construction quality of deep piles in waterproof curtain is often unstable. The waterproof effect is not easy to guarantee $[5,6]$.

The anti-side stiffness of the underground diaphragm wall is large, which can effectively control the deformation of the foundation pit, and the waterproof effect is better. It can greatly reduce the groundwater leakage problem, but the cost is high.

Compared with the underground diaphragm wall, it costs lower by the bored pileand TRD method.In this way, the cost of foundation pit protection is lower; at the same time, the foundation pit deformation control effect and water stop effect are better[7,8].

After comprehensive comparison, the project adopts the structure of the retaining structure of the bored pile + TRD method.

At present, the underground main structure of the project has been completed. The results of foundation pit monitoring show that from the excavation of the foundation pit to the backfilling of the basement, the accumulated settlement of the adjacent viaduct pier is about $4 \mathrm{~mm}$, and the monitoring data of the surrounding wall and surrounding environment are within a reasonable and controllable range.

\section{China Ocean Terminal Project}

The proposed site is located in the south of Weishan Road in Pudong New Area, west of Puming Road, adjacent to Huangpu River and about 70m away from Huangpu River. The project has a four-story basement with an excavation area of about $7,500 \mathrm{~m}^{2}$ and a foundation pit excavation depth of $17.75 \mathrm{~m}$. The west side of the foundation pit is the Huangpu River, and the anti-smashing wall is about $63.5 \mathrm{~m}$ away from the excavation side line of the foundation pit; the south side of the foundation pit is the WeishanThirdVillage of the residential area, and the residential building is about $50.3 \mathrm{~m}$ away from the excavation side line of the foundation pit.

\subsection{Geological Conditions}

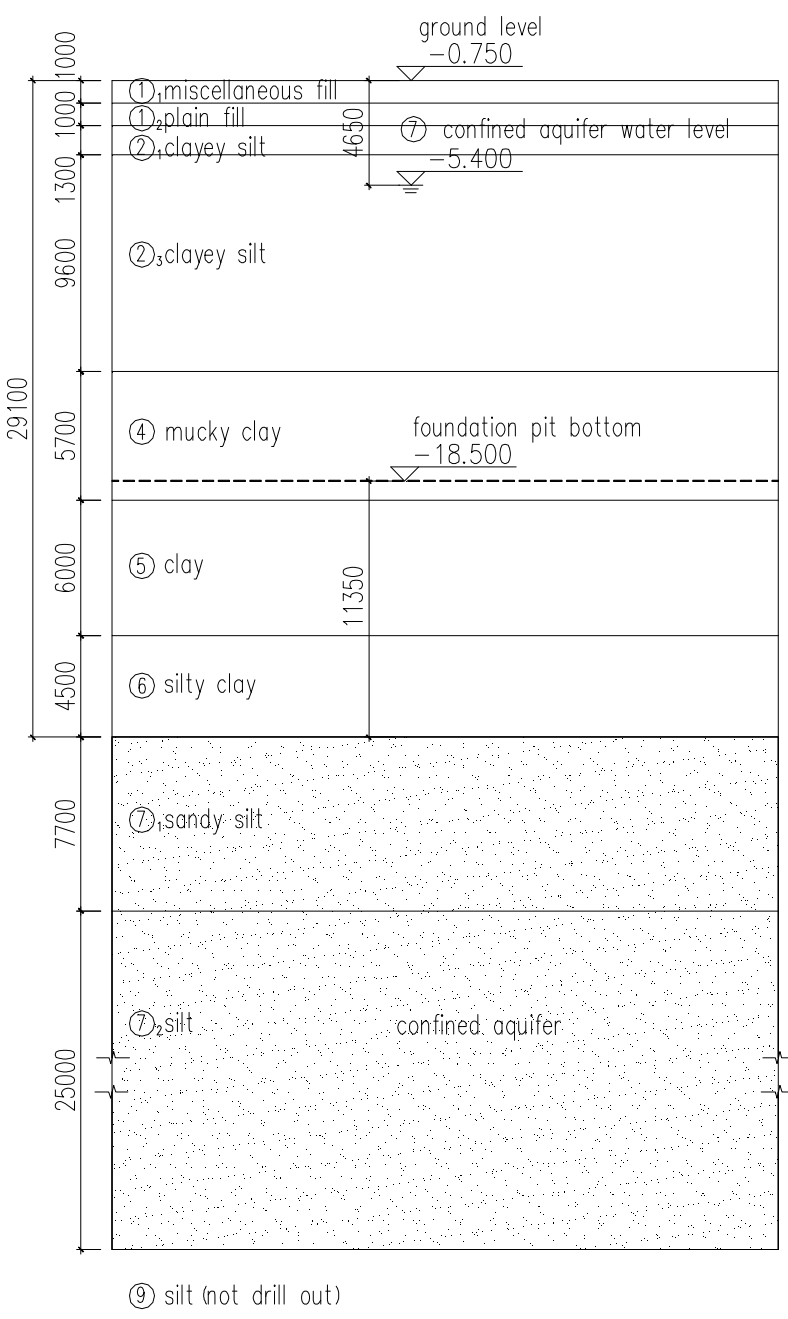

Figure 2. The site geological conditions. 
There are the $(7)_{1}$ layer and the $(7)_{2}$ layer confined aquifers under the site, which have the following characteristics: i) The confined water head is higher: According to the observation results of confined water during the detailed survey, the maximum water level of the confined water is $4.65 \mathrm{~m}$; ii)The buried depth of the confined water is deeper: the buried depth of the (7) floor is about $29 \mathrm{~m}$, about $11 \mathrm{~m}$ away from the bottom of the foundation pit; iii) the confined aquifer is thicker: the thickness of the (7) layer is about $7.7 \mathrm{~m}$, and the thickness of the $(7)_{2}$ layer is about $25 \mathrm{~m}$. And the eighth layer of soil is missing, and the $(7)_{2}$ layer is directly connected to the (9) layer of confined aquifer, so that the $(7)_{1}$ layer, the $(7)_{2}$ layer, and the (9) layer are collectively used as confined aquifers with a layer thickness of more than $45 \mathrm{~m}$. The site geological conditions are shown in Figure 2.

\subsection{Deep-Foundation Pit Support Design}

The retaining structure of the "two walls in one" underground diaphragm wall is adopted.The underground diaphragm wall has the dual functions of retaining soil and stopping water; the horizontal support system is four reinforced concrete internal supports.

After the anti-surge stability check, the (7) layer of confined aquifer may have a sudden water-inrush, and the water level of the confined aquifer needs to be reduced during the excavation process.

On the west and south sides of the foundation pit, there are buildings (structures) that need to be protected.And adjacent to the Huangpu River, in order to reduce the impact of the confined water on the surrounding environment, the waterproof curtain should completely block the (7) confined aquifer.

Because the confined water in the site is deeper and the confined aquifer is thicker, if the (7) and (9) confined aquifers are cut off, the length of the waterproof curtain is more than $75 \mathrm{~m}$. Obviously, based on the reality, the confined water is not very suitable for this project. However, the influence of the pumping of the confined water on the surrounding environment can be reduced by appropriately lengthening the insertion depth of the waterproof curtain in the confined aquifer and extending the seepage path.

\subsection{Comparison of Waterproof Curtain Schemes}

Based on the implementation of the project and the construction experience in Shanghai, the waterproof curtain can be compared in the underground diaphragm wall, tri-axial deep stirring pile and TRD method.

Underground diaphragm wall: The calculation shows that the ground wall insertion ratio is 1:0.85, that is, the ground wall insertion depth is about $15 \mathrm{~m}$, which can meet various stability requirements. According to the calculation and analysis, the ground wall is inserted into the (7) layer of confined aquifer about $4.0 \mathrm{~m}$, and the stability of groundwater impermeability can meet the requirements.

Since the ground wall does not block the confined water inside and outside the foundation pit, the dewateringof the deep-foundation pit will have a certain impact on the surrounding environment. According to the numerical simulation of deep-foundation pit dewatering, the settlement of the top of the ground wall caused by the dewatering in the pit is about $7 \mathrm{~mm}$, and the surface settlement within $50 \mathrm{~m}$ around the deep-foundation pit is about $4 \mathrm{~mm}$, which satisfies the deformation requirements of the surrounding environment.

Tri-axial deep stirring pile: The construction experience in Shanghai shows that when the pile depth is deep, the verticality is not easy to control, and the bottom of the pile is prone to splitting, and the waterproof effect is not easy to guarantee.

TRD method: Combined with the plane view pattern of the foundation pit of the project, the northwest corner of the foundation pit is a smooth circular arc section, but this method is more difficult for the construction of the arc section and the turning section, and the construction cost is higher than that of the underground diaphragmwall[9].

The comparison of theconstruction period and cost of the three waterproof curtains is shown in Table 2.

Table 2. The comparison of the construction period and cost of the three waterproof curtains.

\begin{tabular}{|c|c|c|c|}
\hline type & underground continuous wall & ultra-deep tri-axial mixing pile & TRD method \\
\hline $\begin{array}{l}\text { construction } \\
\text { period }\end{array}$ & $\begin{array}{l}\text { simultaneously constructedwith the } \\
\text { surrounding structure, do not occupy the } \\
\text { construction period separately }\end{array}$ & $\begin{array}{l}\text { shall be carried out prior to the construction } \\
\text { of underground continuous wall, and the } \\
\text { construction period shall be about } 30 \text { days }\end{array}$ & $\begin{array}{l}\text { shall be carried out prior to the construction } \\
\text { of underground continuous wall, and the } \\
\text { construction period shall be about } 30 \text { days }\end{array}$ \\
\hline $\begin{array}{l}\text { construction } \\
\text { cost }\end{array}$ & $\begin{array}{l}\text { Constructedwith the surrounding structure } \\
\text { or plain concrete section is set at the } \\
\text { bottom, the comprehensive cost is low }\end{array}$ & $\begin{array}{l}\text { full section setting is required, the } \\
\text { comprehensive cost is high }\end{array}$ & $\begin{array}{l}\text { full section setting is required, the } \\
\text { comprehensive cost is highest }\end{array}$ \\
\hline
\end{tabular}

After comprehensive comparison and analysis, the underground diaphragm wall scheme is superior to other schemes in terms of construction period and cost, or from the aspects of deep-foundation pit engineering safety and surrounding environmental protection.

\section{Discussion}

Based on the study of the selection and design of the waterproof curtains in the two deep-foundation pits adjacent to the Huangpu River area, it shows that for the three-floorunderground or more than three floorsunderground, the deep-foundation pit excavation may involve the problem of the micro-confined water of the $(5)_{2}$ sandy silt stratum and the confined water of the (7) fine sand layer.

According to the different depth and thickness of the micro-confined aquifer and the confined aquifer, the drop-bottom or pensile waterproof curtain is usually used to control the influence of the confined water on the surrounding environment of the foundation pit [10]. 
When the micro-confined aquifer and the confined aquifer have a shallow burial depth and thickness, the drop-bottom waterproof curtain had better to be used to block the confined water inside and outside the pit, which eliminates the impact of the confined water onthe surrounding environment.

When the micro-confined aquifer and the confined aquifer have deep burial depth or large thickness, considering the economic requirements of the project, it is better to use a pensile waterproof curtain and ensure that the waterproof curtain is inserted into the confined aquifer to a certain depth, which can reduce the adverse impact of confined water on the surrounding environment.

For three floors underground or more than three floorsunderground, the waterproof curtain of the deep-foundation pit can usually be compared and chosen in the tri-axial deep stirring pile, TRD method and underground diaphragm wall. For acertain project, the specific type of waterproof curtain should be determined through comprehensive comparison of technical and economic conditions according to the geological conditions of the project and the surrounding environment.

\section{Conclusion}

Based on the distribution characteristics of burial depth and thickness of confined aquifers adjacent to Huangpu River, this paper summarizes two engineering examples for the complexity of confined water of the deep-foundation project in threefloorsunderground or more than three floors underground. It summarizes the treatment method of the confined water problem in the deep-foundation pit project and the selection of the waterproof curtain, which shows that for the waterproof curtain of the deep-foundation pit in threefloorsunderground or more, considering the large construction depth, the TRD method and the underground diaphragm wall are better. The conclusion of this study can provide a reference for the design of similar deep-foundation pit engineering.

\section{References}

[1] Weng Q P, Wang W D. Design and application of control of confined groundwater in deep foundation pits $[\mathrm{J}]$. Chinese Journal of Geotechnical Engineering, 2008, 10 (S30): 343-348.

[2] Dai B, Wang W D. Discussions on technologies of deep foundation pit projects affected by confined water[J].Chinese Journal of Geotechnical Engineering,2006, 11 (S28): 1659-1663.
[3] Liu G B, Wang W D. Foundation pit engineering handbook (second edition) [M]. Beijing: China Architecture\&Building Press, 2009.

[4] Yang J B, Zhang C B, Gu Y P, et al. Analysis of the heave-piping stability of foundation pits based on a Monte-Carlo method[J].Shanghai Land \&Resources, 2014, 35 (3): 78-81.

[5] Yang X J, Jiang W H. Application of extra-deep tri-axial mixing pile water-stop curtain in deep excavation pit [J]. Underground Engineering and Tunnels, 2009, 1: 28-34.

[6] Zhang Z X, Li X, Xie Z L, et al. Technology of ultra-deep tri-axial cement-soil mixed piles and its application in deep excavation $[\mathrm{J}]$. Chinese Journal of Geotechnical Engineering, 2010, 32 (S2): 383-386.

[7] Song Z J, Hua S H, You X C. Key problems and countermeasures for implementation of TRD construction method for deep and large foundation [J]. Building Construction, 2014, 12: 1325-1326.

[8] Wu J M, Zhang G L.Application forms of TRD method in deep foundation excavation in soft soil [J]. 2014,13:23-26.

[9] Wang W D, Di G E. Engineering practices of constant thickness steel cement-soil wall constructed by TRD method[J] Chinese Journal of Geotechnical Engineering, 2012, 11 (S34): 628-633.

[10] Huang X L, He Y, Zhan G H. analysis of the optimization of deep-foundation pit dewatering design and the effect of a waterproof curtain[J].Shanghai Land \&Resources, 2014, 35 (2): 25-27.

\section{Biography}

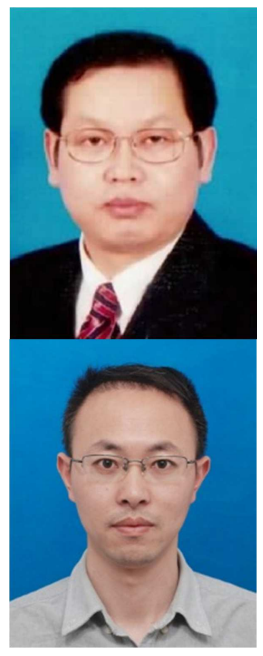

Yang Jibao (1965-), Male, Doctor of Engineering, Professor of Engineering, Mainly engaged in geotechnical engineering investigation and design research

Dong Linbing (1988-), Male, Master of Engineering, Geotechnical Engineer, Mainly engaged in geotechnical engineering design and research. 